\title{
Relationship of Iron Consumption with Ferritin Levels in First-Trimester Pregnant Woman in Agam District, 2019
}

\author{
Diva Yulferina*, Vaulinne Basyir, Dessy Arisanty and Nur Indrawaty Lipoeto \\ Faculty of Medicine, Andalas University, Padang 25138, Indonesia \\ *Corresponding author
}

\section{A B S T R A C T}

Iron has an important role in various metabolic processes and as a central structure of hemoglobin $(\mathrm{Hb})$ for the process of transporting oxygen. Malnutrition from the beginning of pregnancy until the end of pregnancy will cause problems with labor, premature birth, low birth weight in infants to maternal death. The importance of examining serum Ferritin levels as early detection of iron deficiency anemia is especially carried out before pregnancy or early pregnancy (trimester I), given the high incidence of iron deficiency anemia in pregnant women and its impacts. The purpose of this study is to look at the relationship of iron consumption with Ferritin levels in first-trimester pregnant women in Agam Regency in 2018. This research is observational with cross-sectional study. The study was conducted at the Biomedical Laboratory of Andalas University from February 2019 to January 2020 with a sample of 60 respondents. Sampling is done by consecutive sampling technique. Measurement of daily iron consumption with FFQ interviews, and measurement of Ferritin levels using ELISA. Data were analyzed using Person correlation test and abnormal data with non-parametric Person correlation test. 17 respondents (28.3\%) with iron RDA $<30 \mathrm{mg}$, and 43 respondents (71.7\%) with iron RDA sufficient. 17 respondents (28.3\%) with Ferritin levels $<30 \mu \mathrm{g} / \mathrm{L}$ and 43 respondents $(71.7 \%)$ with enough Ferritin. It was found that there was a significant relationship between iron consumption with Ferritin levels in first-trimester pregnant women with a p-value $=0.003$ $(\mathrm{p}<0.05)$, with a correlation value of 0.373 which indicates the direction of a positive relationship with weak strength. There was a significant relationship between iron consumption and Ferritin levels in first-trimester in pregnant women with correlation values indicating a positive relationship with weak strength.

\section{Introduction}

Nutrition is an important aspect of development, can contribute to improving the quality of resources so that it can play a maximum role in development. Nutrition adequacy is very important for all individuals, starting from pregnancy, infants, toddlers, children, adolescents, adults to the elderly. ${ }^{2}$ Anemia is a health disorder that is often encountered during pregnancy. ${ }^{2}$ In 2011 the World Health Organization (WHO) estimated the prevalence of anemia in pregnant women globally to reach $38 \%$, which is as many as 32 
million people. Groups that are prone to anemia are those aged 15-49 years. around the world. Around $40-88 \%$ of maternal deaths in developing countries are associated with anemia in pregnancy. World Health Organization (2013) reports that prevalence shows that around $35-75 \%$ of cases of maternal deaths occur as a result of this and iron deficiency anemia is one of the 1 leading causes of death in pregnant women in the world. $^{3}$

In 2017 the prevalence of anemia cases in pregnant women in West Sumatra Province was $7.32 \%$. As many as $9.3 \%$ of pregnant women suffer from anemia and are spread in various work areas of Peblic Health Center in Padang City. In 2016 in the city of Bukittinggi, the incidence of anemia in pregnant women was $24 \%$ and was still below the target of $<8.9 \%$. In 2015, there was $15.4 \%$ incidence of anemia in pregnant women in Agam District where this figure had increased from the previous year which was $14.7 \%$. $^{4}$

The causes of anemia during pregnancy among women in various countries are varied and multifactorial. Anemia is generally caused due to poor consumption of nutrients and iron deficiency. ${ }^{5}$ Pregnant women are the most vulnerable to malnutrition, due to an increase in the nutritional needs of the mother and fetus during pregnancy. During pregnancy, the cause of anemia is increased oxygen demand.

As a result, red blood cells (erythrocytes) increased by $20-30 \%$. However, this increase is not proportional to the progressive increase in plasma volume of $40-45 \%$, resulting in the process of hemodilution (blood-thinning) which causes a decrease in Ferritin levels, so anemia increases during pregnancy. Pregnant women need twice the iron to meet the needs of the mother and fetal growth, so the need to meet the consumption of quality iron during pregnancy, so that the chance of anemia is decreased. ${ }^{6}$

Iron has an important role in various metabolic processes and as a central structure of hemoglobin $(\mathrm{Hb})$ for the transport of oxygen. ${ }^{1}$ The need for iron during pregnancy has increased by $1,000 \mathrm{mg}$, with a proportion of $300 \mathrm{mg}$ for the fetus and placenta, $500 \mathrm{mg}$ for expansion of maternal $\mathrm{Hb}$, and the remaining $200 \mathrm{mg}$ is discharged normally through the skin, urine, and digestive tract. ${ }^{1}$

Iron metabolism is influenced by various factors, one of which is protein. Protein has an important role which is to provide consumption of organic iron (haem), organic iron (haem) obtained from food consumption, especially on red meat, and as an important functional unit to bind iron and prevent the potential for toxic oxidants in the form of hemoprotein as a heme compound (hemoglobin or myoglobin), heme enzymes, and nonheme compounds (Ferritin). ${ }^{7}$

Ferritin is an iron storage protein and is extracellular in serum. Ferritin functions as a clinical marker of the body's iron stores status. In iron homeostasis, Ferritin is influenced by cellular iron concentration (the amount of cellular iron concentration is directly proportional to the amount of Ferritin produced). Furthermore, between intracellular and extracellular Ferritin the amount of iron in intracellular stored is directly proportional to the amount of serum extracellular Ferritin or serum Ferritin.

Serum Ferritin examination was chosen because it is the most accurate test for diagnosing iron deficiency anemia. Ferritin serum examination is proven to be the earliest indicator. Ferritin levels decrease when depletion of iron stores and during pregnancy will decrease due to hemodilution. Low Ferritin values can be caused by several 
things, such as acute blood loss (1-2 weeks), chronic blood loss such as gastrointestinal hemorrhage, malabsorption syndrome, increased iron requirements such as pregnancy, menstruation, growing children, and iron deficiency. Serum Ferritin levels are considered as a cut-off point in pregnant women between $12-30 \mu \mathrm{g} / \mathrm{mL}$. It is said to have an iron deficiency if the Ferritin level is $<12 \mu \mathrm{g} / \mathrm{mL}$ and is said to be insufficient and needs precautions such as compliance with iron intake and $\mathrm{Fe}$ tablets which is <30 $\mu \mathrm{g} / \mathrm{mL}^{8}{ }^{8}$

The results carried out by Brow (2008) said that intake of Iron and Zinc has a strong relationship. It states that there is an interaction between micronutrients. ${ }^{9}$ The results of a study in Bolivia also mentioned that of $95 \%$ of pregnant women in the first trimester, only $42 \%$ had anemia due to iron deficiency. ${ }^{8}$

WHO previously reported that the prevalence of pregnant women with iron deficiency was around $35-75 \%$ and increased with increasing gestational age and it was estimated that 30$40 \%$ caused iron deficiency anemia due to iron deficiency. Iron deficiency anemia is also caused due to insufficient intake of iron-rich foods.

These nutritional factors are caused by lack of intake or poor quality of iron because the amount of intake is apparently not enough to prevent anemia, but the quality of iron must also be considered in the selection of foods to be consumed to meet the body's need for iron. ${ }^{10}$

The results of a study conducted by Citra Dewi (2018) in the Padang City found that the mean serum Ferritin levels of anemia pregnant women in the low category $(11.13 \pm$ $6.37 \mu \mathrm{g} / \mathrm{L})$ with $\mathrm{p}<0.05$, which means that there is a relationship between Ferritin levels serum pregnant anemia with birth weight babies born in the working area of the Lubuk Buaya Public Health Center in Padang City.

\section{Materials and Methods}

This research was an observational with a cross-sectional study. ${ }^{11}$ Ferritin examination was carried out in the Biomedical Laboratory of the Faculty of Medicine, Andalas University and an interview with the FFQ (Food Frequency Questionnaire) to measure iron daily consumption, and this research has been conducted from February 2019 - January 2020. The population in this study were all first-trimester pregnant women in Agam Regency. The research subjects chosen are those that meet the inclusion and exclusion criteria. Where the inclusion criteria are firsttrimester pregnant women 9-12 weeks of pregnancy, do not consume drugs metabolic syndrome. The number of subjects was calculated using the Nden Hypothesis Test Formula, based on the formula the results of 60 research samples were obtained.

Ferritin examination by the method by ELISA, filling the FFQ (Food Frequency Questionnaire) to measure daily food consumption. Data were analyzed using Person correlation test and abnormal data with non-parametric Person correlation test with p-value $<0.05$, it was considered that there were statistically significant differences.

\section{Results and Discussion}

Based on table 1, the average age of respondents is $(29.28 \pm 5.263)$ years, most respondent's education level is high school $(33.3 \%)$, as many as $(81.7 \%)$ respondents are not working, and the age of pregnancy is 1112 weeks ( $45.7 \%)$.

Based on table 2, the average value of iron consumption in first-trimester pregnant 
women in the Agam Health Center is (37.28 \pm 13.59) $\mathrm{mg}$. A total of 17 respondents $(28.3 \%)$ with iron consumption $<30 \mathrm{mg}$ and with sufficient iron consumption (71.7\%).

Based on table 3, it was found that the mean Ferritin levels in first-trimester pregnant women in the Agam Health Center were $(54.16 \pm 35.87) \mu \mathrm{g} / \mathrm{L} .17$ respondents $(28.3 \%)$ with Ferritin levels $<30 \mu \mathrm{g} / \mathrm{L}$ and with adequate Ferritin levels (71.7\%).

Based on table 4, it was found that there was a significant relationship between iron consumption with Ferritin levels in firsttrimester pregnant women with p-value = $0.003(\mathrm{p}<0.05)$. The correlation value is 0.373 which indicates the direction of a positive relationship with a weak strength.

Agam Regency is a hilly or mountainous and coastal area that is dominated by protected areas on the basis of an agricultural economy, dry land plantations and horticulture. In the field of agriculture, majority of the community on this district has land to be cultivated into paddy fields by planting rice, besides that it is also used to grow chili, corn, pulses, and others. All of these agricultural, plantation and livestock farming certainly contain a lot of vitamins and minerals when processed, especially iron which will be consumed daily by humans. ${ }^{12}$

Pregnant women were aged under 20 years and above 35 years are very risky to get pregnant. The age of the mother who is still too young is related to the reproductive organs of the mother that have not been fully formed, this will also result in a high rate of maternal mortality due to the risk of bleeding and anemia. If a pregnant woman is under 20 years, the iron intake will be divided between her biological growth and the fetus in the womb. Pregnant women who are above 35 years will experience the physiological function of the body is not optimal, because it has entered the early degenerative period. The age factor is a factor that needs to be considered for a woman to get pregnant. ${ }^{13}$

Pregnant women are one of the groups prone to malnutrition, due to an increase in nutritional needs to meet the needs of the mother and fetus. Poor eating patterns in pregnant women have an impact on the occurrence of nutritional disorders including anemia, weight gain in pregnant women and impaired fetal growth. ${ }^{14}$

During pregnancy there is a significant increase in the need for iron to increase red blood cell mass and expansion of plasma volume for fetal growth. In addition, iron is also needed to form hemoglobin in the red blood cells of the mother and fetus. During pregnancy, the need for iron increases by $30 \%$ compared to not getting pregnant. ${ }^{15}$

The level of education is very influential on changes in attitudes and healthy living behavior. In this study, the education of most respondents was high school $(33.3 \%)$ where maternal education was one of the determinants of nutritional status, and maternal, infant, and child mortality. ${ }^{16}$ Education is one of the measures used in socioeconomic status. Pregnant women who have less education, will affect the ability of mothers to obtain information about anemia in pregnancy. ${ }^{17}$

This is according to Rachmaniar's research (2013). According to educational background, it turns out that more sample education is found with high school education at $62.0 \%$, this is also one of the factors that can cause anemia. $^{18}$ Iron intake is the first line that determines a person's iron reserves in the next process. If the amount of iron that enters is small, then the body will compensate for increasing absorption which is illustrated by the increased binding capacity of iron. However, if the intake is never met the longer 
the iron reserves in the body will continue to decrease even depleted because it is used for erythropoiesis. This is indicated by the depletion of iron deposits and reduced saturation of transferrin, in this stage there has been a condition of iron deficiency that is not accompanied by anemia, if the iron reserves run out, then of course erythropoiesis will be disrupted, whereas in the process of erythropoiesis it is needed Iron which binds with protoporfirin for forming heme, because no Iron is bound there is an increase in free protophorphyrin followed by a decrease in serum Ferritin levels. ${ }^{19}$

If this continues, the amount of $\mathrm{Hb}$ will decrease further, resulting in Iron deficiency anemia. $^{20}$ Pregnant women should eat foods with high iron content, such as whole grains, red meat, nuts, green vegetables, and liver. Consumption of adequate vitamin $\mathrm{C}$ can also increase the process of absorption of iron in the body. ${ }^{20}$

Based on the table above, it can be seen that although most pregnant women consume enough iron, there are still many pregnant women who have not consumed iron adequately and well. This must be considered, given the iron must always be in a sufficient state, both before and after pregnancy to prevent anemia even worse iron deficiency anemia during pregnancy.

This is because, the presence of iron content in foods that may not be digested properly such as cereals and nuts and other vegetable matter, because these foods contain ingredients that can inhibit absorption in the intestine, most of the iron will not be absorbed and disposed of with feces. ${ }^{21}$ Optimal nutritional regulation during pregnancy will have positive outcomes, but the state of malnutrition can have adverse effects on the health and development of the fetus. The need for food consumed by pregnant women is not only emphasized in the amount of the dose but on the nutritional value or quality. In addition to high quality, the amount of nutrients consumed by pregnant women needs to be regulated properly, because an iron deficiency in daily food can sustainably increase the risk of nutritional anemia. Lack of knowledge about foods that contain a lot of nutrients as well as food processing methods and proper eating patterns are indirect factors for anemia in pregnant women. $^{22}$

Ferritin and hemoglobin levels are often used to measure iron deficiency anemia, especially in the population of pregnant women. The amount of Ferritin and hemoglobin content in the body can determine the amount of body iron reserves and functional iron circulating in the blood. In the metabolism of iron, the body's iron reserves will be mobilized if the functional iron is not sufficient to meet the body's iron needs. If this situation continues it can cause iron deficiency to anemia conditions. Ferritin is in the blood in very low concentrations, whereas plasma Ferritin is in balance with the Ferritin reserves in the body, and will decrease in concentration when an iron deficiency occurs. Low Ferritin serum concentration is a sensitive indicator of iron deficiency. ${ }^{23}$

According to the conclusions of the study, the pattern of consumption of women in Indonesia is generally more than vegetable ingredients where iron levels in vegetable sources are known to have low iron quality and for absorption requires the help of a booster. Ferritin levels are often used to measure iron deficiency anemia, especially in populations. The Ferritin levels can determine the number of iron reserves in the body and functional iron circulating in the blood. In the metabolism of iron, the body's iron reserves will be mobilized if the functional iron is not sufficient to meet the body's iron needs. If this 
situation continues it can cause iron deficiency to anemia conditions. During pregnancy, pregnant women need 1000 iron while the daily diet can only absorb $10-15 \%$ of the non-heme iron consumed. In addition, women's consumption patterns in Indonesia generally contain low-quality iron. Food sources are more abundant than vegetables, where iron levels in vegetable sources are known to have low iron quality and absorption requires the help of stimulants such as ascorbic acid. ${ }^{24}$

This has been proven in Thailand that the main cause of anemia in pregnant women is due to iron deficiency (43.1\%.) Likewise, a study in Tanzania shows that anemia in pregnant women is related to iron deficiency (p-value $=0.03)$, vitamin A $(p$-value $=0.004)$ and nutritional status (MUAC) (pvalue $=0.003) .{ }^{25}$ There is a close correlation between anemia during pregnancy with fetal death, abortion, birth defects, low birth weight of the baby, reduced iron reserves in children or children born in a state of nutritional anemia. Low intake of iron into the body from consumption of iron from daily food is one of the causes of anemia. ${ }^{26}$

Sabriani's research (2015) on the relationship of Ferritin levels and protein intake in pregnant women Chi-Square test results at a 95\% confidence level showed an association between Ferritin levels and protein intake in pregnant women in North Bolaang Mongondow District ( $\mathrm{p}$-value=0.019). Ferritin is an important protein in iron metabolism. Under normal conditions, Ferritin stores iron that can be taken back for use as a necessity. In excess iron, the body's iron stores are greatly increased and far more Ferritin is present in tissues, such as the liver and spleen. $^{27}$

Table.1 Characteristics of Respondents

\begin{tabular}{|c|c|}
\hline Characteristics & Frequency $(n=60)$ \\
\hline Age (Year) $($ Mean \pm SD $)$ & $29.28 \pm 5.263$ \\
\hline $\begin{array}{l}\text { Last Education } \\
\text { Elementary School (\%) } \\
\text { Junior High School (\%) } \\
\text { High School }(\%) \\
\text { Degree }(\%)\end{array}$ & $\begin{array}{l}7(11.7) \\
17(28.3) \\
20(33.3) \\
16(26.7)\end{array}$ \\
\hline $\begin{array}{l}\text { Occupation } \\
\text { Working }(\%) \\
\text { Not working }(\%)\end{array}$ & $\begin{array}{l}11(18.3) \\
49(81.7)\end{array}$ \\
\hline 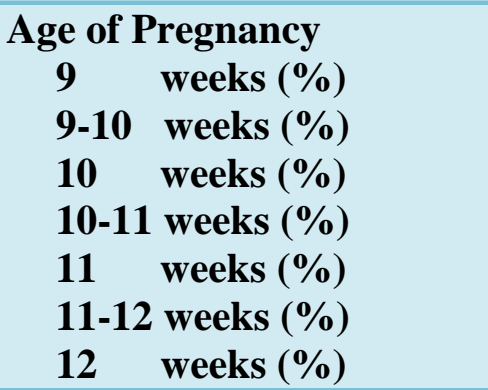 & $\begin{array}{c}2(3.3) \\
6(10.0) \\
2(3.3) \\
15(25.0) \\
3(5.0) \\
28(45.7) \\
4(6.7)\end{array}$ \\
\hline
\end{tabular}


Table.2 Iron Consumption in First-Trimester Pregnant Women in Agam Health Center

\begin{tabular}{|c|c|c|}
\hline Iron Consumption (mg) & $\begin{array}{c}\mathbf{f}(\boldsymbol{\%}) \\
\mathbf{n = 6 0}\end{array}$ & $\begin{array}{c}\text { Mean } \mathbf{\pm} \text { SD } \\
(\mathbf{m g})\end{array}$ \\
\hline $\mathbf{2 3 0}$ & $43(71.7)$ & $37.28 \pm 13.59$ \\
\hline$<\mathbf{3 0}$ & $17(28.3)$ & \\
\hline
\end{tabular}

Table.3 FerritinLevels in First-Trimester Pregnant Women at Agam Health Center

\begin{tabular}{|c|c|c|}
\hline Ferritin Levels $(\boldsymbol{\mu g} / \mathbf{L})$ & $\begin{array}{c}\mathbf{f}(\boldsymbol{\%}) \\
\mathbf{n = 6 0}\end{array}$ & $\begin{array}{c}\text { Mean } \pm \mathbf{S D} \\
(\boldsymbol{\mu g} / \mathbf{L})\end{array}$ \\
\hline $\mathbf{3 0}$ & $43(71.7)$ & $54.16 \pm$ \\
\hline$<\mathbf{3 0}$ & $17(28.3)$ & 35.87 \\
\hline
\end{tabular}

Table.4 Relationship of Iron Consumption with Ferritin Levels in First-Trimester Pregnant Women in Agam Health Center

\begin{tabular}{|c|c|c|c|c|}
\hline Variables & $\mathbf{n}$ & Mean \pm SD & p-value & Korelasi (r) \\
\hline Iron Consumption $(\mathbf{m g})$ & 60 & $37.28 \pm 13.59$ & 0.003 & 0.373 \\
\hline FerritinLevels $(\boldsymbol{\mu g} / \mathbf{L})$ & 60 & $54.16 \pm 35.87$ & & \\
\hline
\end{tabular}

\section{Conclusion and recommendation}

There is a significant relationship between iron consumption with Ferritin levels in firsttrimester pregnant women with $\mathrm{p}$-value $=$ $0.003(\mathrm{p}<0.05)$. The correlation value is 0.373 which indicates the direction of a positive relationship with weak strength. It is hoped that further researchers will be able to measure maternal hemoglobin levels, as well as carry out continuous FFQ assessments of mothers in subsequent studies. It is hoped that further researchers will be able to continue this research with other variables such as macro substances or other micro substances on the first-trimester Ferritin levels.

\section{References}

1. Brise, H. 2000. Influence of Meals on Iron Absorbsion in Oral Iron Therapy.Acta Med Scand, 39-45.
2. Almatsier, S. 2004. Prinsip Dasar Ilmu Gizi. Jakarta: Gramedia Pustaka Utama.

3. World Health Organization. 2011. Iron deficiency anemia: Assessment, prevention and control-a guide for programme managers. Geneva

4. Badan Pusat Statistik, Badan Pusat Statistik Kabupaten Agam, 2015.

5. Citra, kesuma. 2012. Anemia Gizi: Masalah Asupan Zat Gizi Ibu Hamil 8 dan Pencegahannya. Yogyakarta: Kalika

6. Shankar M dan Sharma J B. 2010 Anemia in pregnancy in New delhi, India. JIMSA. Vol. 23. No 4 Oktober 2010

7. Cohen, H., \& Haas, D. 2008. Hemoglobin Correction Factors for Estimating the Prevalence of Iron Deficiency at High Altitudes in Bolivia. Pan Am J Public Health, 392 -399

8. Hwang,\&Ji-Yun. 2013. Maternal Iron Intake at Mid -pregnancy is Associated 
with Reduce Fetal Growth. Nutrition Journal, 12 -38.

9. Brown, K., Wuehler, S., \&Peerson, J. 2008.Food and Nutrition Buletin.The Importance of Zinc in Human Nutrition and Estimation of Global Prevalence of Zinc Deficiency.

10. Madhavi LH, Singh HKG. 2011. Nutritional status of rural pregnant woman. People's J Sci Res. 2011;4:2023.

11. Notoatmodjo. 2010. Metodologi Penelitian Kesehatan. Jakarta : PT. Rineka Cipta.

12. Data Dinas Pertaniandan Peternakan Kabupaten Agam, 2017

13. Departemen Kesehatan R.I. Program Penanggulangan Anemia Gizi pada Wanita Usia Subur (WUS); (Safe Motherhood Project: A Partnership and Family Approach). Direktorat Gizi Masyarakat. Jakarta: Direktorat Jenderal Bina Kesehatan Masyarakat Depkes, 2005

14. Ojofeitimi EO, Ogunjuyigbe PO, Sanusi, et al., Poor Dietary Intake of Energy and Retinol among Pregnant Women: Implications for Pregnancy Outcome in Southwest Nigeria. Pak. J. Nutr. 2008; 7(3):480-484.

15. Scholl TO. 2005. Iron status during pregnancy: setting the stage for mother and infant. Am J Clin Nutr 81:1218S22S.

16. Bencaiova G, Burkhardt T, Breymann C. 2012. Anemia-prevalence and risk factors in pregnancy. Eur J Intern Med 23(6); 529-533.http://dx.doi.org/10.1016/j. ejim.2012.04.008

17. Timmreck C. Epidemiologi Suatu Pengantar, Pekerjaan dan Pendidikan Sebagai Karakteristik Orang. 2005. Jakarta: Penerbit Buku Kedokteran, EGC

18. Rachmaniar. et al., 2013. Hubungan antara pengetahuan tentang anemia pada ibu hamil trimester II dan III dengan resiko terjadinya anemia dalam kehamilan di puskesmas sukorame kediri. Fakultas Kedokteran Universitas Muhammadiyah Malang. Vol. 9 No.2 Desember 2013.

19. Sacher R, McPherson R. Kimia Umum. Tinjauan Klinis Hasil Pemeriksaan Laboratorium, Edisi 11. EGC. 2004;

20. Masrizal, 2007. Anemia defesiensi Zat Besi. Jurnal kesehatan masyarakat, September 207, II (1) : 140-145. Fakultas Ilmu Kesehatan Unand.

21. Ningrum.. Pemberian Tablet Fe Pada Ibu Hamil Untuk Mencegah Anemia. 2009. Http://Ningrumwahyuni.Wordpress.Com/ 2009/09/04/PemberianTablet-Fe-PadaIbu-Hamil-Untuk-Mencegah-Anemia

22. Idrus, Dwiyana Ocviayanti. Gizi ibu hamil. 2008. Jakarta: PT Gaya Paovorit Press

23. Shao J, Lou J, Rao R, Georgieff MK, Kaciroti N, Felt BT, Zhao ZY, Lozoff B. Maternal Serum Ferritin Concentration Is Positively Associated with Newborn Iron Stores in Women with Low Ferritin Status in Late Pregnancy. J. Nutr. 2012;142(11):2004-9.

24. Allen LH. 2000. Anemia and iron deficiency: effects on pregnancy outcome. Am J Clin Nutr 71:1280S-4S.

25. Hinderaker SG, Olsen BE, Lie RT, et al., Anemia in pregnancy in rural Tanzania: associations with micronutrients status and infections. Eur. J. Clin. Nutr. 2002; 56(3):192-199.

26. Beck, E Mary (2000). Nutrition and dietitcs for nurse. New York ;Aspen Publisher.

27. Sabriani, pontoh (2015). Hubungan Kadar Ferritin dan asupan protein pada ibu hamil trimester II-III di kabupaten Bolang Mongondow utara. 


\section{How to cite this article:}

Diva Yulferina, Vaulinne Basyir, Dessy Arisanty and Nur Indrawaty Lipoeto. 2020. Relationship of Iron Consumption with Ferritin Levels in First-Trimester Pregnant Woman in Agam District, 2019. Int.J.Curr.Microbiol.App.Sci. 9(03): 1507-1515. doi: https://doi.org/10.20546/ijcmas.2020.903.176 